\title{
気液交番環境中の鋼の腐食速度に及ぼす海水成分の影響
}

\author{
大谷恭平*，塚田 隆，上野文義，加藤千明
}

国立研究開発法人日本原子力研究開発機構

\section{Effect of Seawater Components on Corrosion Rate of Steel in Air/solution Alternating Condition}

\author{
Kyohei Otani* ${ }^{*}$ Takashi Tsukada, Fumiyoshi Ueno and Chiaki Kato \\ Japan Atomic Energy Agency \\ *責任著者(Corresponding Author) 319-1195 那珂郡東海村大字白方 2-4 (2-4 Shirakata, Tokai-mura, 319-1195, Japan) \\ E-mail: otani.kyohei@jaea.go.jp
}

\begin{abstract}
The purpose of this study was to investigate the effect of artificial seawater components on the corrosion rate of carbon steel under air/solution alternating condition, and to clarify the corrosion mechanism of carbon steel that changes with artificial seawater concentration. Mass measurements showed that the corrosion rate of carbon steel in the alternating condition accelerates with increasing concentration in the concentration region between deionized water to 200 times diluted artificial seawater(ASW), and the corrosion rate decreases with increasing concentration in the concentration region between 20 times diluted ASW to undiluted ASW. It can be considered that the reason why the carbon steel corrosion was suppressed in highly concentrated artificial seawater would $\mathrm{Mg}$ ions and $\mathrm{Ca}$ ions in the artificial seawater precipitate and cover on the surface due to the increase in $\mathrm{pH}$ near the surface by oxygen reduction reaction.
\end{abstract}

Key words : Carbon steel, Iron rust, Corrosion, Water film, Metal cation, Seawater, SEM, Polarization curve

1. 緒言

東京電力福島第一原子力発電所の原子炬格納容器 (PCV) 内には冷却水が循環注入されており, 円滑な廃炉 作業を達成するために $\mathrm{PCV}$ 等の材料である炭素鋼の腐 食速度を把握する必要がある。原子炉内部調查 ${ }^{1)}$ より, 現在原子炬の鋼は気水界面環境に曝されていることが確 認された。山本ら ${ }^{2)}$ は鋼材が気水界面のような環境に曝 されると, 濡れ乾き部ではなく常に液膜が存在して濡れ ている箇所で腐食速度が最大になると報告している，更 に, 鋼材は表面に薄い液膜が存在する条件下では，水溶 液中に比べて腐食速度が加速すると報告されている ${ }^{3)-6)}$. すなわち, PCV 内面の気水界面付近では鋼材の腐食は加 速される可能性が高い. 以上の理由から, 既報では気水 界面を模擬した気中と液中に交互に曝される環境 $($ 気液 交番環境)における炭素鋼の腐食速度を回転型腐食試験 装置により調査し ${ }^{7)}$, 気液交番環境では気中に晒されて いる間は鋼材表面に液膜が存在すること，気液交番環境 では常時水中にある場合に比べ腐食速度が 3-5 倍に増大 することを示した．更に気液交番環境で鋼表面に形成し た鉄さび層の断面観察および分析を実施した既報 ${ }^{8), 9)}$ で は，気液交番環境では鋼が液膜環境下に暴露されると複 雑な多層構造の鉄さび層が形成し，その鉄さび層の構造 に起因して常に速いカソード反応速度が維持されて鋼の 腐食速度が増大したと推定できることを示した。

実機環境では初期に海水が注入された後に淡水処理さ れた冷却水が循環注入されたため PCV 内部の海水成分 濃度は $10 \mathrm{ppm}$ 程度の低い值まで低下していると報告さ れている ${ }^{10)}$. このことは PCV 内部の材料は多様な濃度
の海水に晒されたことを意味しているため，異なる濃度 の海水環境における PCV 構成材料の腐食速度を把握し ておく必要がある。海水に含まれる多様な成分の中で, $\mathrm{Mg}^{2+}$ や $\mathrm{Ca}^{2+}$ については $\mathrm{CaCO}_{3}$ や $\mathrm{Mg}(\mathrm{OH})_{2}$ が鋼の表面 に析出することで腐食量を減少させるという報告はある が ${ }^{11)}$, 腐食加速が懸念される気液交番環境における鋼の 腐食挙動に及ぼす海水濃度やその成分の影響については 明らかになっていない。

本研究では, 気液交番環境における炭素鋼の腐食速度 に及ぼす海水成分の影響を調査し，更に腐食試験後の炭 素鋼表面に形成した鉄さび層の観察および分析や電気化 学測定から海水成分による炭素鋼の腐食機構に及ぼす影 響を見出すことを目的とする。

\section{2. 実験}

\section{1 試験溶液}

本研究では Table 1 に組成を示す 3 種類の試験溶液を 用いた。市販の人工海水 (Biz Science Ltd., Aquamarine) に加えて, 比較のために人工海水と塩化物イオン $\left(\mathrm{Cl}^{-}\right)$ 濃度が同一な $\mathrm{NaCl}$ 溶液および人工海水と $\mathrm{Cl}^{-}, \mathrm{Mg}^{2+}$, $\mathrm{Ca}^{2+}$ の濃度が同一な溶液も使用した。以降，人工海水を $\mathrm{ASW}, \mathrm{NaCl}$ 溶液を $\mathrm{NaCl}$, 人工海水 $(\mathrm{ASW})$ とカチオン濃 度 $\left(\mathrm{Mg}^{2+}, \mathrm{Ca}^{2+}\right)$ が同一な溶液を $\mathrm{CCS}$ (Cation Containing Solution) と呼称する. 各試験溶液は 2000 倍希釈 $(1 / 2000)$, 200 倍希釈 $(1 / 200), 20$ 倍希釈 $(1 / 20)$, 原液 (Undiluted) と濃度を変えて試験に使用し，比較のために純水中でも 試験を実施した。異なる濃度の試験溶液の $\mathrm{Cl}^{-}$濃度, 電 気伝導度および溶存酸素 (DO) 濃度を Table 2 に示し, こ れらの值は 3 種類の $\mathrm{ASW}, \mathrm{NaCl}, \mathrm{CCS}$ 間でほとんど差 はなかった。 


\section{2 回転型腐食試験 $\left.{ }^{7)}-9\right)$}

回転型腐食試験装置について説明する。炭素鋼試料は Fig. 1のようにアクリル製の試料固定治具ごと試験溶液 中で矢印の方向に定速で回転させた．試験槽内の液面の 位置を(1)の位置にすることで試料が常時水中で回転す る条件 (常時浸漬回転)および静止する条件(常時浸漬静 止) とし, 液面の位置を(2)の位置にすることで気中と液 中へ交互に曝される条件(気液交番) とした。試験水槽を 恒温槽内に設置することにより希釈人工海水の温度を一 定に保持した。空気バブリングにより試験溶液は常に酸 素飽和に保持し, 各種センサーにより液中および気中の 温度, 液中の DO 濃度を測定し, 大きな変動が無いこと を確認した。

Table 3 に組成を示すSGV480の JIS 規格に準拠した $\mathrm{PCV}$ 構造材料相当の炭素鋼 (サイズ : $40 \times 10 \times 2 \mathrm{~mm}$, 固 定ネジ孔径： $3 \mathrm{~mm}$ )の表面を $\mathrm{SiC}$ 研磨紙で\#800まで研 磨後, エタノール中で 10 分間超音波洗浄を行い試料と して用いた。濃度の異なる 3 種類の試験溶液中で 500 時 間試験を実施した。試験槽内の気相部は大気開放とし た. 試験中の試験溶液の条件は以下の通りである; $\mathrm{pH}$ : $6 \pm 0.5$, 温度 : $30 \pm 1^{\circ} \mathrm{C}$. 試料固定治具は 60 秒に 1 回転 の一定速度で連続回転させた(試料表面での相対流速は
約 $0.003 \mathrm{~m} \mathrm{~s}^{-1}$ ). 試験前後の質量変化を電子天秤によっ て測定した。質量測定用の試料は腐食試験終了後に $55^{\circ} \mathrm{C}$ に保持した防錆剂 (Asahi Chemical Ltd., イビットNo.2S) を 0.3 mass\%含む 5.0 mass \% 塩酸溶液中に 5 分間浸漬す ることで表面の鉄さび層のみを脱膜した．断面観察用の 試料は, 試験終了後にエタノールに浸漬してから十分に 乾燥させた後, 真空含浸装置を用いて鉄さび層ごと樹脂 埋めした。樹脂埋め後の試料はファインカッターにより 切断し, その断面を $\mathrm{SiC}$ 研磨紙およびコロイダルシリカ を用いて平滑にしてから観察および分析を行った。観察 はデジタルカメラ (Panasonic Inc., DMC-TZ40), 走査型 電子顕微鏡 (SEM, JEOL Ltd., JSM-7000F) を用いて行い, 鉄さびの定性分析は SEM 付属のエネルギー分散型 X 線 分光器 $(\mathrm{EDS})$ を用いて行った.

\section{3 電気化学試験}

異なる濃度の人工海水が炭素鋼の表面反応に及ぼす影 響を調査するため, 電気化学試験として動電位分極測定 を実施した。炭素鋼 $(10 \times 10 \times 2 \mathrm{~mm})$ に導線を接続した 後に樹脂埋め後, 表面を $\mathrm{SiC}$ 研磨紙で\#800 まで研磨し, エタノール中で 10 分間超音波洗浄を行い試料極 $\left(1.0 \mathrm{~cm}^{2}\right)$ として用いた，対局には白金板 $\left(6.0 \mathrm{~cm}^{2}\right)$, 参照極には飽

Table 1 Chemical composition of test solutions (mM).

\begin{tabular}{cccccccccc}
\hline & $\mathrm{NaCl}$ & $\begin{array}{c}\mathrm{MgCl}_{2} \\
\cdot 6 \mathrm{H}_{2} \mathrm{O}\end{array}$ & $\mathrm{NaSO}_{4}$ & $\begin{array}{c}\mathrm{CaCl}_{2} \\
2 \mathrm{H}_{2} \mathrm{O}\end{array}$ & $\mathrm{KCl}$ & $\mathrm{NaHCO}_{3}$ & $\mathrm{KBr}$ & $\mathrm{H}_{3} \mathrm{BO}_{3}$ & $\begin{array}{c}\mathrm{SrCl}_{2} \cdot \\
6 \mathrm{H}_{2} \mathrm{O}\end{array}$ \\
\hline $\mathrm{ASW}$ & 419.8 & 54.7 & 28.8 & 10.4 & 9.3 & 2.4 & 0.84 & 0.44 & 0.27 \\
$\mathrm{NaCl}$ & 559.8 & - & - & - & - & - & - & - & - \\
$\mathrm{CCS}$ & 429.6 & 54.7 & - & 10.4 & - & - & - & - & - \\
\hline
\end{tabular}

Table 2 Chloride concentration, Electrical conductivity, and DO concentration of test solutions at each dilution ratio.

\begin{tabular}{cccccc}
\hline Dilution ratio & $\begin{array}{c}\text { Deionized } \\
\text { water }\end{array}$ & $1 / 2000$ & $1 / 200$ & $1 / 20$ & Undiluted \\
\hline $\begin{array}{c}\text { Chloride concentration } \\
(\mathrm{mM})\end{array}$ & 0 & 0.28 & 2.8 & 28.0 & 559.8 \\
$\begin{array}{c}\text { Electrical conductivity } \\
(\mathrm{mS} / \mathrm{cm})\end{array}$ & 0.0004 & 0.04 & 0.38 & 3.4 & 55.4 \\
$\begin{array}{c}\text { DO concentration } \\
(\mathrm{ppm})\end{array}$ & 9.2 & 9.2 & 9.2 & 9.1 & 7.4 \\
\hline
\end{tabular}

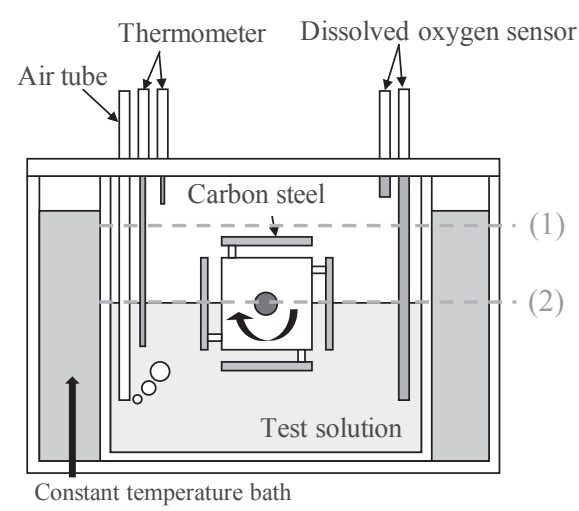

Table 3 Chemical composition of the carbon steel (mass \%).

\begin{tabular}{|c|c|c|c|c|c|c|}
\hline & $\mathrm{C}$ & $\mathrm{Si}$ & $\mathrm{Mn}$ & $\mathrm{P}$ & S & $\mathrm{Fe}$ \\
\hline SGV480 & $\leqq 0.28$ & $\begin{array}{l}0.13- \\
0.45\end{array}$ & $\begin{array}{c}0.79- \\
1.30\end{array}$ & $\leqq 0.035$ & $\leqq 0.035$ & bal. \\
\hline
\end{tabular}

Fig. 1 A schematic image of the rotating corrosion equipment during the corrosion tests. 
和 $\mathrm{KCl}-\mathrm{Ag} / \mathrm{AgCl}$ 電極 (SSE) を用いた．動電位分極測定は 異なる濃度の試験溶液に 10 分間浸漬した後，ポテンショ スタット(Ivium Technologies Inc., pocket STAT)によっ て電位走査速度 $0.5 \mathrm{mV} \mathrm{s}^{-1}$ で自然浸漬電位からカソード 側に- $1.0 \mathrm{~V}$ まで，アノード側に $-0.3 \mathrm{~V}$ まで走査した。 温度は $298 \mathrm{~K}$ に保持した。測定は 3 回以上行い, 再現性 のあるデータを結果として採用した。

\section{3. 結 果と考察}

\section{1 腐食速度}

Fig. 2 に気液交番環境で純水中および濃度の異なる各 試験溶液中で腐食試験を実施した際の炭素鋼の腐食速度 を示す，気液交番環境における ASW 中の炭素鋼の腐食 速度は $1 / 200 \mathrm{ASW}$ で極大となっており，それ以上の濃 度では腐食速度が減少している。特に Undiluted ASW 中 では $1 / 200 \mathrm{ASW}$ と比較して腐食速度が大幅に抑制され ていることがわかる. CCS でも同様に $1 / 200$ CCS で炭 素鋼の腐食速度は極大值をとっている。一方, $\mathrm{NaCl}$ で は $1 / 20 \mathrm{NaCl}$ で腐食速度が極大となり, Undiluted $\mathrm{NaCl}$ でも腐食速度は極大值とほとんど変わらなく, ASW ゃ CCS で見られたような濃度の増大に伴う大幅な腐食速度 の減少は確認できない.

常時水中に浸漬された環境で純水中および濃度の異な る各試験溶液における炭素鋼の腐食速度を Fig. 3 に示 す. Fig. 3(a) は常時浸漬回転, Fig. 3(b) は常時浸漬静止 の条件における腐食速度を表している. Fig. 3(a)の常時 浸漬回転の条件で, ASW の腐食速度はFig. 2 の気液交 番環境と同様に $1 / 200 \mathrm{ASW}$ で極大で，それ以上の濃度 では腐食速度が減少している。CCSでも高濃度側では腐 食速度が減少している傾向が確認できる。一方, $\mathrm{NaCl}$ では気液交番環境とは異なり濃度の増大に伴って腐食速 度が増大していることがわかる. Fig. 3(b)の常時浸漬静 止の条件では, Fig. 3(a) と同様に ASW と CCSでは $1 / 200$ で極大で, それ以上の濃度で腐食速度が減少し, $\mathrm{NaCl}$ では濃度の増加に伴って腐食速度が増大してお り, 回転と静止で傾向に変化はない. $\mathrm{NaCl}$ 溶液で海水 と同程度の塩化物イオン濃度になるまでは濃度の増大に 伴って鋼の腐食速度が増大するのは既存の報告と一致し

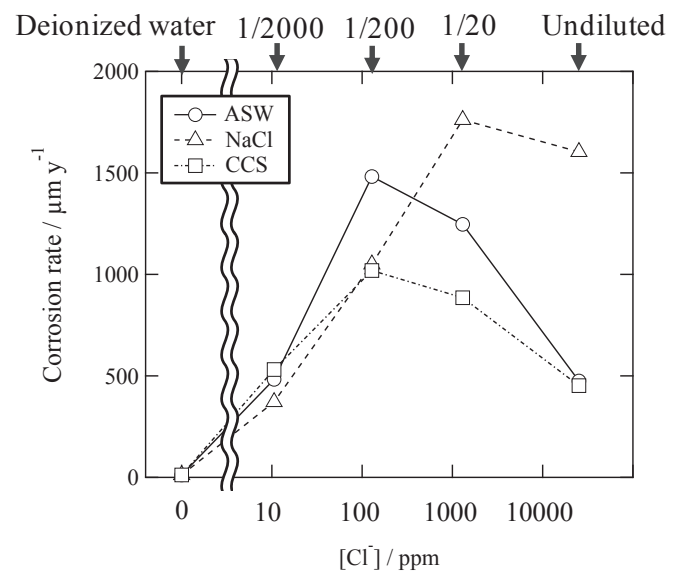

Fig. 2 Corrosion rate of carbon steel in various test solutions with different concentrations under air/solution alternating condition. (a) Rotating immersion condition

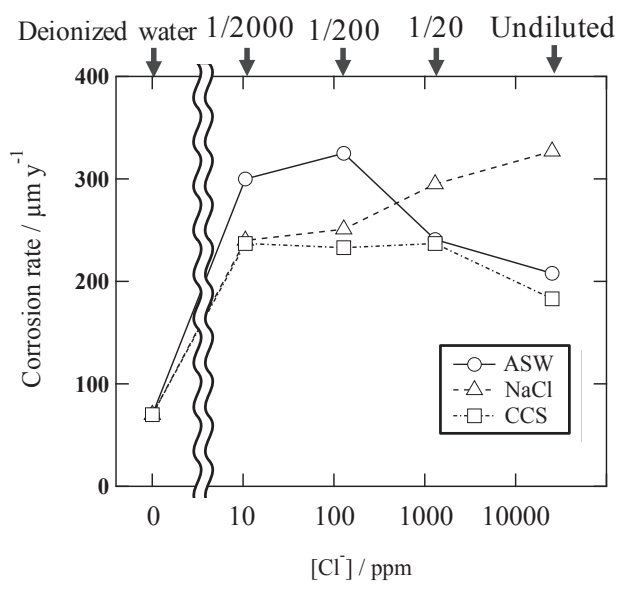

(b) Stationary immersion condition

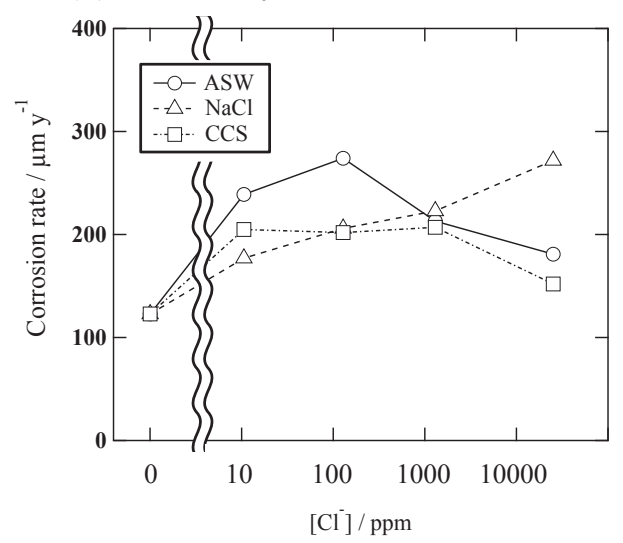

Fig. 3 Corrosion rate of carbon steel in various test solutions with different concentrations under (a) rotating immersion condition and (b) stationary immersion condition.

ているため ${ }^{12)-14)}$, 本研究で使用した回転型腐食試験装 置で妥当なデータが得られると考えられる.

Fig. 2 およびFig. 3 より，どの条件でも腐食速度は ASW および CCS では $1 / 200$ で極大值をとり， $\mathrm{NaCl}$ では 無希釈や $1 / 20$ で極大值をとることがわかった. Table 2 に示すパラメータは試験溶液の種類ごとに差はないた め, 溶液ごとの相違点は Table 1 に示す化学組成の差の みである. $\mathrm{NaCl}$ と $\mathrm{CCS}$ では $\mathrm{Mg}^{2+}$ および $\mathrm{Ca}^{2+}$ の濃度の みが異なっていることがTable 1 より確認できため, こ れらの金属カチオンにより腐食を抑制する効果を発揮し たと推察できる。

\section{2 断面 SEM 写真}

既報 ${ }^{9)}$ で気液交番環境において鋼が液膜環境下に暴露 されて複雑な多層構造の鉄さび層が形成し，その構造に 起因してカソード反応速度は常時浸漬条件に比べて加速 されて腐食が加速すると報告した．特に多層構造の鉄さ びに存在する密な $\mathrm{Fe}_{3} \mathrm{O}_{4}$ の最外層 (クラスト層 (Rust crust layer) と呼称)が, 腐食速度の維持に寄与していたと示唆 する結果が得られている ${ }^{9)}$ 。すなわち, 鋼の腐食速度を 考える上で鉄さび中のクラスト層の有無を確認する必要 がある，そこで，気液交番環境で鋼に形成する腐食生成 物の構造に及ぼす人工海水濃度の影響を調査するため, 腐食生成物の断面観察を実施した. Fig. 4 に気液交番環 
境において各濃度の ASW で腐食試験を実施した後の試 料断面 SEM 写真を示す. Fig. 4 中に矢印で示す層が気 液交番環境で鋼の腐食速度を増大するクラスト層であ る. Fig. 4(b)より，1/200 ASW で形成した鉄さび層は最 外層にクラスト層が存在していることわかる. 既報 ${ }^{9)}$ よ り, クラスト層と鉄素地は電気伝導性の高い多孔質の $\mathrm{Fe}_{3} \mathrm{O}_{4}$ 層を通じて電気的に接続していることが確認され ている. そのため, 最も溶存酸素濃度の高い最外層にあ るクラスト層はカソード反応界面になると考えられる.

Fig. 2 より，1/2000 ASW 中の鋼の腐食速度は 1/200 ASW に比べて遅かったが, Fig. 4(a) から 1/2000 ASW で形成 した腐食生成物にもクラスト層が形成していることがわ かる. Fig. 4(c)より，1/20 ASW で炭素鋼に形成した鉄 さび層は $1 / 200 \mathrm{ASW} に$ 比べてクラスト層は確認しにく くなっていた. Fig. 4(d)より, Undiluted ASW 中で形成 した鉄さび層にはクラスト層自体確認できないことがわ かる.

\section{3 断面 EDS 分析}

Fig. 1 および Fig. 2 の結果より, 高濃度の ASW や CCS で腐食が減少するのは溶液に含まれる $\mathrm{Mg}$ や Ca イ オンの影響が示唆された。 そこで, これらの金属カチオ ンの表面への析出を確認するため, 1/20 ASW および Undiluted ASW 中での試料断面の EDS 分析を実施した.

Fig. 5 に気液交番環境で形成した鉄さび層の断面 EDS
マッピング分析結果を同一箇所の SEM 写真に重ねた画 像を示す。分析箇所は Fig. 4(c) および $(\mathrm{d})$ と同じ領域で ある. Fig. 5(a) は 1/20 ASW 中で形成した鉄さび層の断 面 EDS 分析結果で，枠外に示す範囲が鉄さび層全体の 範囲, 白い破線で囲む領域がクラスト層を表す。画像中 でオレンジ色の領域が $\mathrm{Mg}$ を含んでいることを意味す る. EDS マッピングより，1/20 ASW で形成した鉄さび 層には外側に $\mathrm{Mg}$ を含む領域が存在している。 また, 図 中に示す十字点は EDS 点分析の位置を示し, その結果 を Table 4(a) に示す. クラスト層より外側の領域である 点 1 および点 2 は, 点分析結果より $\mathrm{Mg}$ および Fe から 成る腐食生成物であり, どちらの点も $\mathrm{Fe} よ り も ~ \mathrm{Mg}$ の 割合が高いことがわかる. クラスト層より内側の領域で ある点 3 は $\mathrm{Fe}$ を主成分とする腐食生成物で, $\mathrm{Mg}$ や $\mathrm{Ca}$ を含まないことがわかる。また，マッピング画像よりク ラスト層の外側近傍で $\mathrm{Mg}$ の濃縮が確認できる. $\mathrm{Mg}$ の 電位 - $\mathrm{pH}$ 図 ${ }^{15)}$ より $\mathrm{Mg}$ イオンは塩基性環境では $\mathrm{Mg}(\mathrm{OH})_{2}$ が安定で, 更に高 $\mathrm{pH}$ 環境では $\mathrm{Mg}(\mathrm{OH})_{2}$ として析出す ると報告されているため ${ }^{16)}$ ，クラスト層の外側近傍は高 $\mathrm{pH}$ 環境であったことが示唆される．このことは，既報 ${ }^{9)}$ で報告したクラスト層の外側が(1) 式に示す酸素還元反 応の反応界面になっているという推察を裏付ける結果で ある。

$$
1 / 2 \mathrm{O}_{2}+\mathrm{H}_{2} \mathrm{O}+2 \mathrm{e}^{-} \rightarrow 2 \mathrm{OH}^{-}
$$

Fig. 5(b) は Undiluted ASW 中で形成した鉄さび層の断

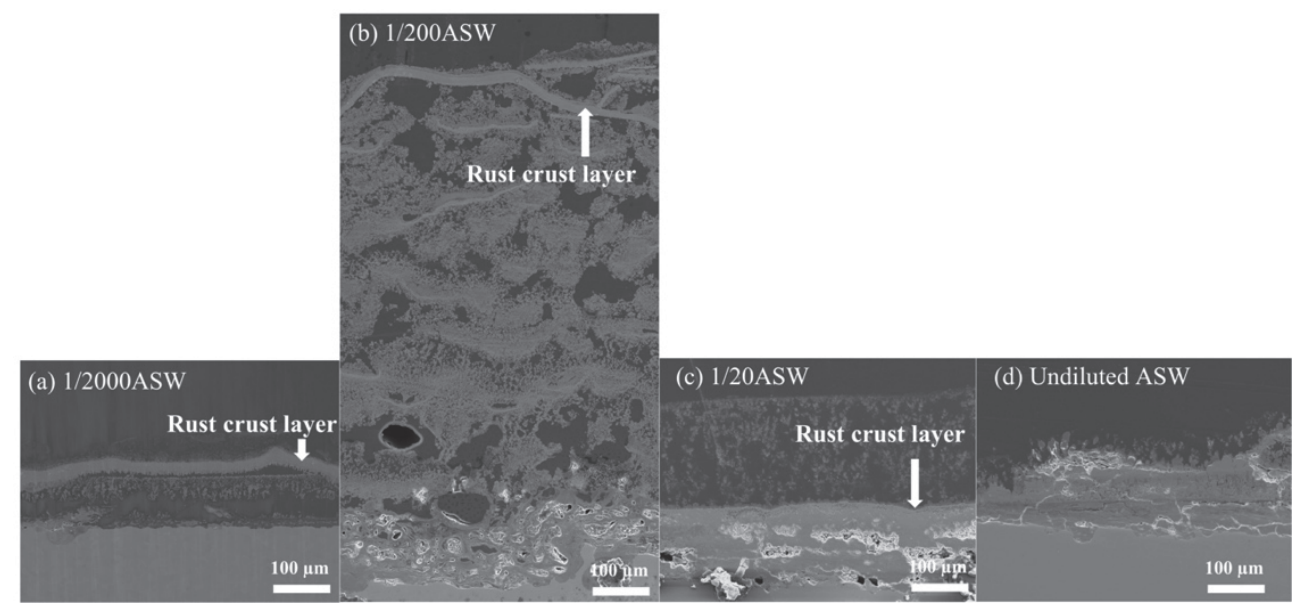

Fig. 4 Cross-sectional SEM images of the specimen after the corrosion tests under air/solution alternating condition in (a) 1/2000 ASW, (b) 1/200 ASW, (c) 1/20 ASW, and (d) Undiluted ASW.
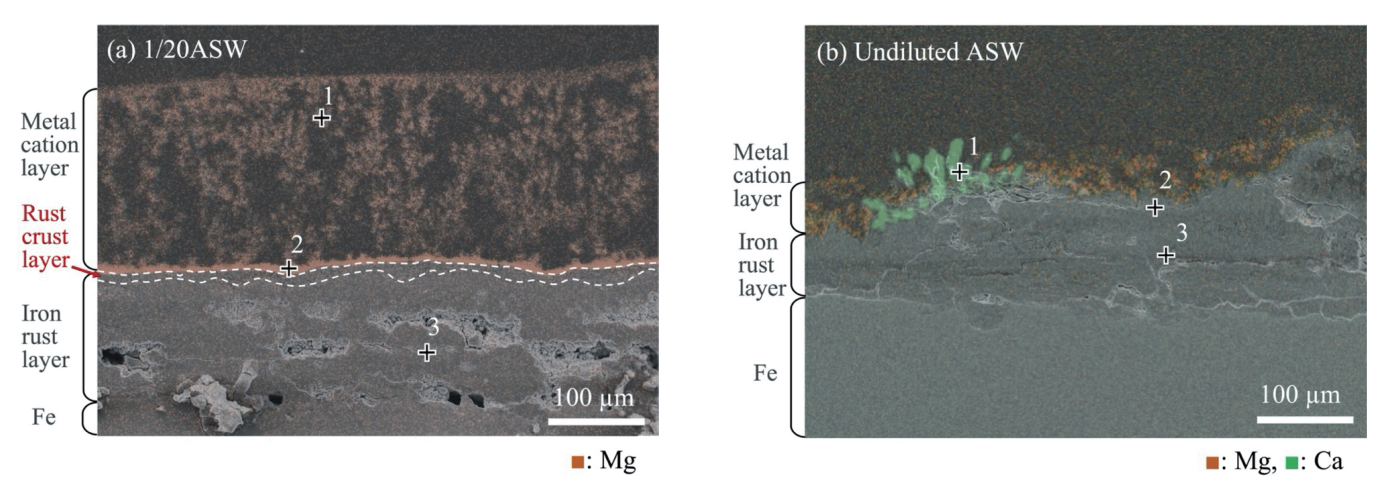

Fig. 5 Cross-sectional EDS mapping images of the specimen after the corrosion tests under air/solution alternating condition in (a) $1 / 20$ ASW and (b) Undiluted ASW. 
Table 4 Cross-sectional EDS point analysis of the specimen after the corrosion test under air/solution alternating condition in (a) 1/20 ASW and (b) Undiluted ASW (at \%).

(a) $1 / 20$ AWS

\begin{tabular}{|c|c|c|c|c|c|}
\hline & $\mathrm{O}$ & $\mathrm{Mg}$ & $\mathrm{Ca}$ & $\mathrm{Cr}$ & $\mathrm{Fe}$ \\
\hline 1 & 75.4 & 18.2 & 0.28 & 0.25 & 5.90 \\
\hline 2 & 53.5 & 36.3 & 0.01 & 0.00 & 10.2 \\
\hline 3 & 35.4 & 0.00 & 0.00 & 0.17 & 64.5 \\
\hline \multicolumn{6}{|c|}{ (b) Undiluted AWS } \\
\hline & $\mathrm{O}$ & $\mathrm{Mg}$ & $\mathrm{Ca}$ & $\mathrm{Cr}$ & $\mathrm{Fe}$ \\
\hline 1 & 63.8 & 0.05 & 35.7 & 0.00 & 0.38 \\
\hline 2 & 41.5 & 1.16 & 0.32 & 0.01 & 57.0 \\
\hline 3 & 41.2 & 0.10 & 0.06 & 0.02 & 58.7 \\
\hline
\end{tabular}

面 EDS 分析結果で，枠外に示す範囲が鉄さび層の範囲 を表す。画像中でオレンジ色の領域が $\mathrm{Mg}$ を含み, 緑色 の領域が Ca を含んでいることを意味する. EDS マッピ ング結果より, Undiluted ASW で形成した鉄さび層には 最外部に $\mathrm{Ca}$ や $\mathrm{Mg}$ が存在していることがわかる. 図中 に示す十字点は EDS 点分析の位置を示し, その結果を Table 4(b) に示す. 鉄さび層には析出物 (点 1) が観察さ れており, EDS 分析より Caの析出物だとわかる。大気 開放下において高 $\mathrm{pH}$ 環境で $\mathrm{Ca}$ イオンは $\mathrm{CaCO}_{3}$ として析 出していると複数の研究から報告されているため ${ }^{11,17)}$, 析出物は $\mathrm{CaCO}_{3}$ だと考えられる. 最外層より内側の領 域である点 2 は $\mathrm{Fe}$ が主成分の $\mathrm{Mg}$ を含む腐食生成物で あると考えられ, 内部の点 3 は Undiluted ASW 中の金属 カチオン成分をほとんど含まない Fe の腐食生成物であ ると考えられる，以上の結果から，気液交番環境におい て 1/20 ASW 中の鋼に形成する鉄さび層の外側に $\mathrm{Mg}$ が 析出し, Undiluted ASW 中では $\mathrm{Mg}$ および Ca が析出す ることが明らかになった。また，1/200 ASW および 1/2000 ASW 中で形成した鉄さび層にはこれらの Mgや $\mathrm{Ca}$ の析出は確認できなかった.

\section{4 濃度の異なる人工海水中における動電位分極曲線}

これまでの結果から 1/20 ASW や Undiluted ASW で腐 食速度が減少する理由として, ASWに含まれる $\mathrm{Mg}$ や Ca の影響が示唆された. 一方, Table 2 に示すように, 無希棌の人工海水では DO 濃度がその他の希釈倍率より 約 1.8 ppm 低いため, Undiluted ASW ではDO 濃度が低 下した影響で $1 / 200$ ASW に比べてカソード反応速度が 減少して腐食速度が減少した可能性がある。 そこで, 炭 素鋼上におけるカソード反応速度に及ぼす溶液濃度の影 響を調查するため, 濃度の異なる $\mathrm{ASW}$ およ゙ $\mathrm{NaCl}$ 中 で動電位分極測定を実施し, 酸素拡散限界電流密度の差 を比較した. Fig. 6 は各濃度の (a) ASW および (b) NaCl 中の動電位分極曲線を示す。動電位分極曲線は縦軸の電 流密度が対数表記になっているため酸素拡散限界電流密 度の差を比較しにくい. (2) 式に関するNernstの式より,
$2 \mathrm{H}^{+}+2 \mathrm{e}^{-} \rightarrow \mathrm{H}_{2}$

中性環境中の水素発生電位は $-0.8 \mathrm{~V}$ 付近であること がわかっているため, 本研究では $-0.8 \mathrm{~V}$ 以上でカソー ド分極曲線の $\mathrm{d}|\mathrm{i}| / \mathrm{dE}$ の值が最小となる点における電流 密度を酸素拡散限界電流密度とした. Fig. 7 に各溶液, 各濃度における酸素拡散限界電流密度を実数で比較した グラフを示し, 酸素拡散限界電流密度の值はASW 濃度 が濃いほど小さいことがわかる。これは，Fig. 2 および Fig. 3 の 1/200 ASW から Undiluted ASW の濃度範囲で は腐食速度が溶液濃度の増大に伴って減少する結果とよ く一致している。一方, Fig. 6(b)の各濃度の $\mathrm{NaCl}$ にお ける動電位分極曲線より, カソード分極曲線は溶液濃度 が変化しても電流密度は ASW に比べて変化が小さいこ とを示唆しており, Fig. 7 の酸素拡散限界電流密度の值 は濃度の増大に伴って減少しているものの, ASW と比 較するとその変化量は極めて小さいといえる。 また, Fig. 6 中のアノード分極曲線より，1/200 から Undiluted

(a) ASW

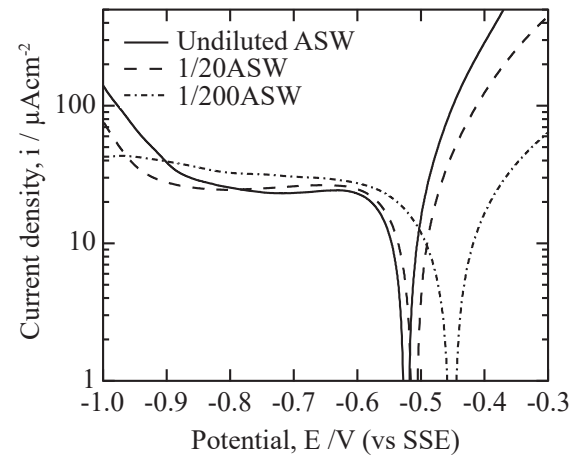

(b) $\mathrm{NaCl}$

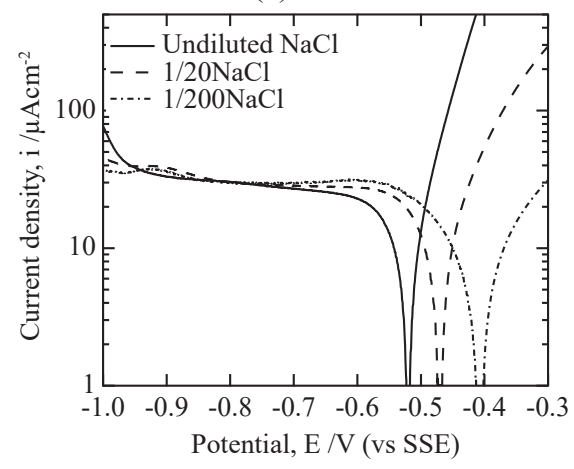

Fig. 6 Polarization curves of carbon steel in test solutions with different concentrations. (a) ASW and (b) NaCl.

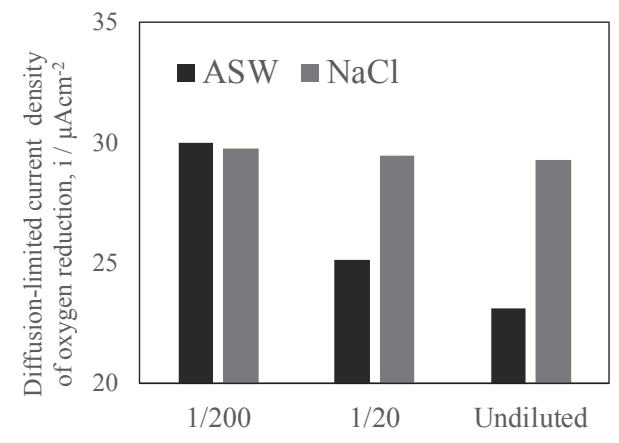

Fig. 7 Diffusion-limited current density of oxygen reduction of carbon steel in test solutions with different concentrations. 
までの範囲の濃度では (3) 式のアノード反応の電流密度 はカソード反応の電流密度に比べると非常に大きく, 一 般に知られている通り本研究の炭素鋼でも腐食反応の律 速過程は酸素拡散限界電流密度に律速するカソード反応 だとわかる。

$$
\mathrm{Fe} \rightarrow \mathrm{Fe}^{2+}+2 \mathrm{e}
$$

$\mathrm{ASW}$ および $\mathrm{NaCl}$ 中での炭素鋼の動電位分極測定よ り, $\mathrm{NaCl}$ における酸素拡散限界電流密度は $\mathrm{NaCl}$ 濃度の 増加による溶液中の DO 濃度の低下によって減少してい ないことから，1/20 ASW や Undiluted ASW 中における 腐食速度が $1 / 200 \mathrm{ASW}$ より遅い理由は溶液濃度の増加 に伴うDO 濃度の減少ではないことが明らかになった。 このことから, 本研究でASW の濃度が濃いほど腐食速 度が減少した理由は溶液中の $\mathrm{Mg}^{2+}$ および $\mathrm{Ca}^{2+}$ の金属力 チオンの影響であると考えられる。

\section{5 金属カチオンによる腐食抑制機構の考察}

本研究の実験結果から, 20 倍希釈以上の濃度の ASW や CCS では鋼表面に析出した金属カチオン層によりカ ソード反応速度が減少し, 腐食速度が減少したと推察で きる，そこで，鋼上に形成する金属カチオン層の腐食抑 制効果に関する研究に基づいて，鋼表面に析出した金属 カチオンが鋼の腐食速度を抑制する機構を考察する。

まず金属カチオン層による鋼の腐食抑制に関する研究 のうち, 武田ら ${ }^{18)}$ は亜鉛めっき $(\mathrm{EG})$ 鋼板の表面に絶縁 性の高い $\mathrm{Zn}(\mathrm{OH})_{2}$ が形成すると半導体的性質を持つ $\mathrm{ZnO}$ の場合より $\mathrm{EG}$ 鋼板の腐食速度は減少すると報告し ている. 理由として，カソード反応サイト上に析出した 絶縁体である $\mathrm{Zn}(\mathrm{OH})_{2}$ がアノード反応サイトからの電 荷移動を抑制し，電荷移動過程が律速となり全体の腐食 速度が減少するためと考察している。本研究の大気開放 した気液交番環境で鋼に形成した金属カチオンの層は $\mathrm{Mg}$ および $\mathrm{Ca}$ の電位 - $\mathrm{pH}$ 図 ${ }^{15), 19)}$ や既往研究 ${ }^{11), 16)-17)}$ より, $\mathrm{Mg}(\mathrm{OH})_{2}$ および $\mathrm{CaCO}_{3}$ であると考えられる．藤田ら ${ }^{20)}$ は $\mathrm{Mg}(\mathrm{OH})_{2}$ の電気抵抗率は $1.0 \times 10^{4} \sim 1.0 \times 10^{5} \Omega \cdot \mathrm{m}$ で, 橋 本らは ${ }^{21)} \mathrm{CaCO}_{3}$ の電気抵抗率は $1.0 \times 10^{8} \sim 1.0 \times 10^{9} \Omega \cdot \mathrm{m}$ と報告しており，定義の上では $\mathrm{Mg}(\mathrm{OH})_{2}$ は絶縁体に近 い電気抵抗率であり, $\mathrm{CaCO}_{3}$ は絶縁体と見なすことがで きる，気液交番環境で鋼に形成する鉄さび層のクラスト 層や内部結晶を構成する $\mathrm{Fe}_{3} \mathrm{O}_{4}$ の電気抵抗率はおよそ $4.0 \times 10^{-3} \Omega \cdot \mathrm{m}$ であるため ${ }^{22)}$, 海水中から析出する $\mathrm{Mg}$ や $\mathrm{Ca}$ の金属カチオン析出物の電気抵抗率は $\mathrm{Fe}_{3} \mathrm{O}_{4}$ に比 ベて極めて高い值であることがわかる.

以上の既往研究を踏まえて, 本研究で鋼表面に析出し た金属カチオンが鋼の腐食速度を抑制する機構を考察す る、まず比較のために金属カチオンを含まない $\mathrm{NaCl}$ に 炭素鋼を浸漬した場合の腐食機構を Fig. 8(a)に示す。こ こで，炭素鋼に形成した Fig. 4 のようにクラスト層を含 む複雑な鉄さび層は図中に Iron rust layer として簡略化 して示した. $\mathrm{NaCl}$ に浸漬した炭素鋼は Fig. 8(a)のよう に式(1)および式 (2)のカソード反応により鉄さび層を形 成すると考えられる. $\mathrm{NaCl}$ 中では $\mathrm{pH}$ の増大によって析 出する金属カチオンが存在せず金属カチオンの析出物が 生じないため, カソード反応界面は鉄さび層の最外部で あると考えられる。そのため, 腐食速度を決定するカ ソード反応速度は酸素拡散速度に律速される。次に金属
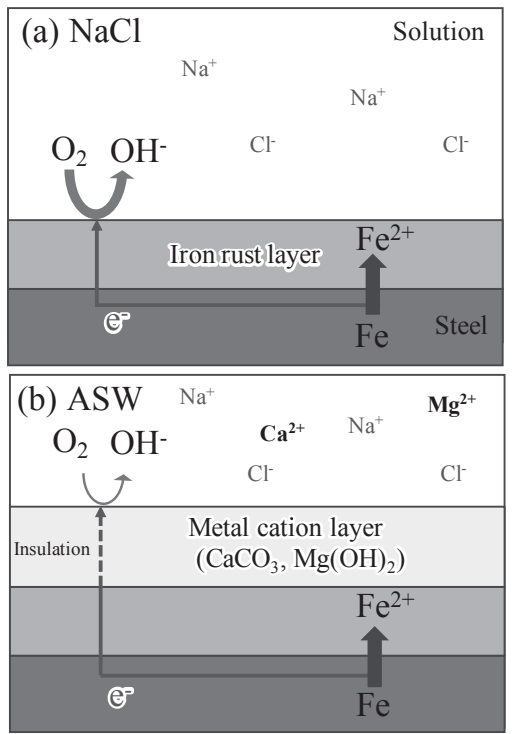

Fig. 8 Schematic diagrams of corrosion mechanism of carbon steel in (a) $\mathrm{NaCl}$ and (b) ASW.

カチオンを含むASW に炭素鋼を浸漬した場合の腐食機 構を Fig. 8(b)に示す. ASW に炭素鋼を浸漬した場合は, 金属カチオンはクラスト層等の反応界面の外側近傍に濃 縮するため, Fig 8(b)のように反応界面に金属カチオン 層が存在する。これらの金属カチオン層は上述したよう に電気抵抗率が高いため, 電荷移動を妨げる効果があ り, 全体の腐食速度は金属カチオン層の電荷移動速度に 律速されると推察する。すなわち, 本研究で濃度の高い ASW や CCS 中で炭素鋼の腐食が抑制された理由は, 溶 液中の金属カチオンが反応界面に $\mathrm{Mg}(\mathrm{OH})_{2}$ や $\mathrm{CaCO}_{3}$ と して析出して反応界面上に存在していたことで，アノー ド反応サイトからカソード反応サイトへの電荷移動が抑 制され，酸素還元反応が抑制されたことに起因している と推察する.

\section{4. 結 論}

気液交番環境における炭素鋼の腐食速度に及ぼす海水 成分の影響を調査し，更に腐食試験後の炭素鋼表面に形 成した鉄さび層の観察および分析や電気化学測定から人 工海水濃度により異なる炭素鋼の腐食機構を考察した結 論を下記に記す。

(1) 炭素鋼の腐食速度は ASW および CCS では 200 倍希 釈で極大值をとり, $\mathrm{NaCl}$ では無希釈や 20 倍希棌で 極大值をとる。

(2) 無希釈を除いた全濃度の ASW で鉄さび層中にクラス 卜層が形成する。

(3) 1/20 ASW 中では Mg 主体の腐食生成物が鉄さびの最 外部に析出し, Undiluted ASW 中では $\mathrm{Mg}$ および Ca を含んだ腐食生成物が析出する.

(4) 常時水中静止条件の炭素鋼の動電位分極測定より, 高濃度の人工海水中でカソード反応速度が減少する 理由は DO 濃度ではなく金属カチオンの影響である ことが示唆された。

(5) 本研究で濃度の高い ASW や CCS 中で炭素鋼の腐食 が抑制された理由は，溶液中の金属カチオンが反応 
界面上に $\mathrm{Mg}(\mathrm{OH})_{2}$ や $\mathrm{CaCO}_{3}$ として析出したこと で,アノード反応サイトからカソード反応サイトへ の電荷移動が抑制され，酸素還元反応が抑制された ことに起因している推察する。

\section{参考 文 献}

1) Tokyo Electric Power Company Holdings, $\langle\mathrm{http} / / / \mathrm{www}$. tepco.co.jp/en/index-e.html $\rangle$ [Accessed March 1, 2020].

2) M. Yamamoto, A. Nogami, J. Torii and A. Matsuoka, ISIJ International, 37, pp.691-696(1997).

3) Y. Hosoya, T. Shinohara, W. Oshikawa and S. Motoda, Zairyo-to-Kankyo, 54, p.391 (2005).

4) M. Yamamoto, H. Katayama and T. Kodama, J. Japan Inst. Met. Mater., 65, pp.465-469 (2001).

5) T. Shinohara, J. Surf. Sci. Soc. Jpn., 36, pp.4-11(2015).

6) A. Nishikata, Zairyo-to-Kankyo, 65, p.120(2016).

7) T. Tsukada and F. Ueno, Proc. 64th Jpn. Conf. Materials and Environments, JSCE, pp.475-478(2017).

8) K. Otani, T. Tsukada and F. Ueno, Proc. 65th Jpn. Conf. Materials and Environments, JSCE, pp.131-134(2018).

9) K. Otani, T. Tsukada and F. Ueno, Zairyo-to-Kankyo, 68, p.205(2019).

10) Y. Fukaya, Corrosion Evaluation and Control of Carbon Steel Facilities in Nuclear Power Plants after a Severe Accident, Tohoku University, Doctoral thesis(2018).
11) T. Kodama and T. Fujii, Boshoku-Gijutsu (presently Zairyoto-Kankyo), 26, p.641(1977).

12) U.R. Evans and T.P. Hoar, Proc. Roy. Soc., A137, pp.343-65 (1932).

13) C.W. Bengough, Ind. Eng. Chem., 29, pp.814-821(1937).

14) G.E. Best and G.W. Mcgrew, Corrosion, 12, pp.286t-292t (1956).

15) M. Pourbaix, Atlas of Electrochemical Equilibria in Aqueous Solutions, NACE, p.141(1996).

16) H. Tsuge, Bull. Soc. Sea Water Sci. Jpn., 51, pp.348-357 (1997).

17) M. Kato, Boshoku-Gijutsu (presently Zairyo-to-Kankyo), 29, p.89(1980).

18) Y. Takeda, A. Ooi, E. Tada and A. Nishikata, Proc. 66th Jpn. Conf. Materials and Environments, JSCE, pp.47-48 (2019).

19) S. Asaoka, T. Okuda, S. Nakai and W. Nishijima, ISIJ International, 53, pp.1888-1893(2013).

20) K. Fujita, T. Katsura, T. Matsuzaki and M. Ichiki, Earth Planets Space, 59, pp.645-648(2007).

21) E. Hashimoto, J. Soc. Chem. Ind. Jpn., 64, pp.250-255 (1961).

22) K. Kaneko, Kinzoku Hyomen Gijutsu, 37, pp.46-54(1986).

(Manuscript received April 16, 2020 ; in final form July 28, 2020)

要旨

本研究では，気液交番環境における炭素鋼の腐食速度に及ぼす海水成分の影響を調査し，更に人工海水 濃度により異なる炭素鋼の腐食機構を明らかにすることを目的とした。その結果より，純水から 200 倍希 釈人工海水までの薄い濃度領域では濃度の増大に伴って腐食速度は加速し，20 倍希釈から無希勫人工海水 までの濃い濃度領域では濃度の増大に伴って腐食速度は減少することを見出した。濃度の高い人工海水中 で炭素鋼の腐食が抑制された理由は，腐食による表面近傍の $\mathrm{pH}$ 増大に伴い人工海水中の $\mathrm{Mg}$ や $\mathrm{Ca}$ イオ ンが反応界面に析出して表面を覆うことで，酸素還元反応が抑制されたためであると考えられる.

キーワード 人工海水, 海水濃度, 金属カチオン, 炭素鋼, 鉄さび, 腐食, 液膜, 動電位分極, SEM 